\title{
The Contribution of Agricultural Sectors on Economic Growth in West Java Province
}

\author{
Yunus Arifien $^{1 *}$, Taufik Rahmat ${ }^{1}$, James Sinurat ${ }^{1}$ \\ ${ }^{1}$ Universitas Nusa Bangsa, Bogor 16166, Indonesia \\ "Corresponding author. Email: yunus@unb.ac.id
}

\begin{abstract}
Economic development is essentially freedom of speech and business that has the aim to improve people's lives, increase employment, smooth income distribution, improve regional relations and efforts to carry out economic activities from the primary sector to the secondary sector. The agricultural sector is larger than the agricultural sector is also relatively faster than the agricultural sector. Therefore, it is necessary to analyse the role of the agricultural sector in the West Java Province and the change in its role in the pace of economic growth using basic economic theory and regional growth theory so that it can be used as planning material that can enhance development that helps the government in the development of development planning. Then the purpose of this study is an analysis of the potential and contribution of the agricultural sector in the provinces of West Java Province and an analysis of the agricultural sector of the regency on the economic growth of the Province of West Java. The method used to analyse is Location Quotient analysis, shift share, and multiple regressions. The results of the analysis of the agricultural sector which is the base sector, namely Kab. Sukabumi, Kab. Cianjur, Kab. Garut, Kab. Tasikmalaya, Kab. Ciamis, Kab. Kuningan, Kab. Cirebon, Kab. Majalengka, Kab. Sumedang, Kab. Indramayu, Kab. Subang, Kab. West Bandung, and Kab. Pangandaran Agricultural sectors that have a significant influence on the rate of economic growth in West Java are Kab. Sukabumi, Kab. Tasikmalaya, Kab. Cirebon, Kab. Sumedang, Kab. Indramayu, Kab. Subang, and Kab. Pangandaran.
\end{abstract}

Keywords: agricultural sectors, economic, growth

\section{INTRODUCTION}

Economic development is essentially a series of policies and businesses that aim to improve people's lives, expand employment, smooth income distribution, improve regional relations and attempt to shift economic activities from the primary sector to the secondary sector. The success of economic development must be able to foster the ability to create a healthy atmosphere of community life and increase the ability for the state and society to expand the availability of better life infrastructure and facilities.

Each region has a style of economic growth that is different from other regions. Therefore the economic development plan of a region first needs to recognize the economic, social and physical character of the region itself, including its interactions with other regions. There is no regional economic development strategy that can apply to all regions. The formulation of regional economic development strategies, both short and long term, an understanding of regional economic growth theory, which is summarized from a study of economic growth patterns from various regions, is one factor that is sufficient to determine the quality of regional economic development plans [1].
Theories of structural change focus on the transformation of economic structures from agricultural patterns to more modern structures and have a resilient manufacturing and service sectors[2]. The economy of a region in the long run will change the structure of the economy which originally relied on the agricultural sector to the industrial sector. From the manpower side, it will cause the movement of workers from the rural agriculture sector to the urban industrial sector, thus causing the contribution of agriculture to decline. Factors causing changes in the structure of the economy include the availability of natural resources, human resources, facilities and infrastructure as well as capital and investment that enters an area.

In line with economic development in the regions, one of the regions that is implementing economic development is the regencies in the province of West Java. The agricultural sector in the province of West Java is a strategic sector that has close links with poverty reduction, efforts to overcome unemployment, efforts to build food security, produce food, environmental preservation efforts and the basis of regional economic development.

Based on data from the Central Statistics Agency on the contribution or growth of the economic sector in West Java Province in 2010-2018, it can be seen that the contribution of the agricultural sector tends to decline and the growth of the agricultural sector is also relatively slow even though the largest GDP distribution of the economic sector comes from the agricultural sector. This shows that there is a tendency for the process of structural transformation in the economy and changes / shifts in the role of the economic sectors in several regencies in West Java Province.

Therefore, it is necessary to analyse the role of the agricultural sector in the West Java Province and the change in its role in the pace of economic growth using an 
economic base theory and regional growth theory approach so that it can be used as a material for planning and evaluation of development that makes it easy for the government to determine development policies. In addition, regencies in the province of West Java will be better equipped to anticipate changes in the role of the agricultural economy. Referring to the problem formulation above, the purpose of this study is:

a. analysis of the potential and contribution of the agricultural sector to the economies of the regencies in West Java Province.

b. analysis of the influence of the agricultural sector from the base regencies on the economic growth of West Java Province.

\section{RESEARCH METHODS}

\subsection{Research Design}

This research uses quantitative descriptive method that is describing things as they are while quantitative is an analysis conducted on data in the form of numbers. The purpose of this study is that the main focus is to analyze the potential and contribution to the economic growth rate of the regencies in West Java Province

\subsection{Data Collection Technique}

The data used are secondary data from 2010 to 2018 data observation period based on constant 2010 prices obtained from the Central Statistics Agency (BPS), the Department of Agriculture, and the Regional Development Planning Agency (BAPPEDA) of West Java Province.

\subsection{Analysis Method}

In this research several analytical techniques are used. This technique is used to help the analysis so that it will get more concrete research results.

\subsubsection{Shift-share analysis}

Shift share analysis is used to determine changes and shifts in the sector of the economy of Bogor Regency. The results of the shift share analysis will illustrate the performance of sectors in the Bogor Regency's GRDP compared to West Java Province. Then an analysis of the deviations that occur as a result of this comparison. If the deviation is positive, then it is said that a sector in Bogor Regency's GRDP has a competitive advantage or vice versa.

\subsubsection{Location Quotient Analysis (LQ)}

If the mainstay sector can be developed properly, it will certainly have a significant influence on regional regional income so that regional economic growth will increase, with the aim of seeing the comparative advantage of a region in determining potential sectors to be developed in. To get the LQ value using a method that refers to the formula stated by Bendavid-Val [3] in his book Kuncoro [4] as follows:

$$
\mathrm{LQ}=\frac{P D R B_{b, i} / \Sigma P D R B_{b}}{P D R B_{s s} / \Sigma P D R B_{s s}}
$$

Where:

$$
\begin{aligned}
& \text { PDRB }_{\mathrm{b}, \mathrm{i}}= \text { GRDP sector } \mathrm{i} \text { in the Regency in a certain year } \\
& \sum \mathrm{PDRB}_{\mathrm{b}}= \text { Total GRDP in the Regency in a particular year } \\
& \text { PDRB }_{\mathrm{ss}}= \begin{array}{l}
\text { PDRB sector } \mathrm{i} \text { in West Java Province in a } \\
\text { certain year }
\end{array} \\
& \sum \mathrm{PDRB}_{\mathrm{ss}}=\begin{array}{l}
\text { Total GRDP in West Java Province in a } \\
\text { particular year }
\end{array}
\end{aligned}
$$

If $\mathrm{LQ}$ is greater than 1 (LQ> 1), the Regency has the potential to develop the sector.

\subsubsection{Analysis of the influence of the regency's agricultural sector on economic growth}

To find out the influence of the regency based agriculture sector on the rate of economic growth in the province of West Java, multiple regression analysis is performed which is a statistical method used to examine the relationship between a dependent variable (Y) economic growth rate with several independent variables (X) LQ base sector regencies.

$\mathrm{Y}=\mathrm{a}+\mathrm{b}_{1} \mathrm{X}_{1}+\mathrm{b}_{2} \mathrm{X}_{2}+\mathrm{b}_{3} \mathrm{X}_{3}+\mathrm{b}_{4} \mathrm{X}_{4}+\ldots \ldots \ldots \ldots+\mathrm{b}_{\mathrm{n}} \mathrm{X}_{\mathrm{n}}$

Where

- Bound Variables (Y) : economic growth rate (\%)

- Independent variable $(\mathrm{X})$ : Regency based agriculture sector

\section{RESULTS AND DISCUSSION}

\subsection{West Java Economy}

The economy of West Java in 2018 saw an increase in performance when compared to 2017 where economic growth was 5.35 percent and in 2018 it increased to 5.64 percent. The GRDP of 2018 based on the constant price in 2010 was 1,419 trillion rupiah while the current price was 1,962 trillion rupiah. If broken down by category, it can be seen that the economic structure of West Java is dominated by businesses in the manufacturing sector. Its role reached 42.16 percent in 2018. Then the wholesale, retail and car and motorcycle repair sectors reached 14.87 percent. The rate of economic growth in West Java ranges between 5.04 $-6.50 \%$. 
Table 1 Contribution and LQ of The Agricultural Sector to GRDP, and The Rate of Economic Growth for The Period 2010 - 2018 For Each Region in West Java [7] - [10]

\begin{tabular}{|llcccccc|}
\hline \multirow{2}{*}{ No } & & \multicolumn{2}{c}{$\begin{array}{c}\text { Agricultural Sector } \\
\text { Contribution }\end{array}$} & \multicolumn{2}{c|}{ LQ Agriculture Sector } & \multicolumn{2}{c|}{ Economic Growth Rate } \\
\cline { 3 - 8 } & & $\mathbf{2 0 1 8}$ & average & $\mathbf{2 0 1 8}$ & average & $\mathbf{2 0 1 8}$ & average \\
\hline 1 & Bogor & 0,05 & 0,05 & 0,64 & 0,64 & 5,21 & 5,86 \\
2 & Sukabumi & 0,22 & 0,22 & 2,64 & 2,64 & 4,68 & 5,26 \\
3 & Cianjur & 0,34 & 0,34 & 3,99 & 3,99 & 4,61 & 5,19 \\
4 & Bandung & 0,07 & 0,08 & 0,98 & 0,98 & 6,25 & 6,07 \\
5 & Garut & 0,37 & 0,37 & 4,41 & 4,41 & 4,14 & 4,65 \\
6 & Tasikmalaya & 0,39 & 0,39 & 4,60 & 4,60 & 3,99 & 4,49 \\
7 & Ciamis & 0,25 & 0,25 & 2,92 & 2,92 & 4,75 & 5,34 \\
8 & Kuningan & 0,24 & 0,24 & 2,87 & 2,87 & 5,20 & 5,85 \\
9 & Cirebon & 0,17 & 0,17 & 1,99 & 1,99 & 4,46 & 5,02 \\
10 & Majalengka & 0,26 & 0,26 & 3,05 & 3,05 & 4,55 & 5,12 \\
11 & Sumedang & 0,17 & 0,18 & 2,42 & 2,43 & 5,83 & 5,18 \\
12 & Indramayu & 0,15 & 0,15 & 2,09 & 1,94 & 1,26 & 1,11 \\
13 & Subang & 0,28 & 0,28 & 3,35 & 3,35 & 6,91 & 7,77 \\
14 & Purwakarta & 0,07 & 0,07 & 0,85 & 0,85 & 5,29 & 5,95 \\
15 & Karawang & 0,04 & 0,04 & 0,46 & 0,46 & 5,09 & 5,73 \\
16 & Bekasi & 0,01 & 0,01 & 0,14 & 0,16 & 5,81 & 5,79 \\
17 & West Bandung & 0,14 & 0,14 & 1,71 & 1,71 & 4,87 \\
18 & Pangandaran & 0,29 & 0,29 & 3,38 & 3,38 & 4,11 & 5,48 \\
\hline
\end{tabular}

West Java Province is one of the agricultural centers in Indonesia where agricultural activities include food crops, plantations, forestry, animal husbandry and fisheries, economic activities of food crops. The agricultural sector is a large contributor to the economy of West Java. The contribution of food crops to the agricultural sector is around 15-16 percent, while rice production contributes 1617 percent. The role of the agricultural sector in the economy of West Java Province in 2010-2018 ranged from $8.55-9.83 \%$

The lowest contribution of the regency's agriculture sector to West Java Province in 2010 - 2018 was Bekasi Regency (0.01 - 0.2\%), Bogor Regency (0.05 - 0.06\%), Kerawang Regency $(0.04-0.05 \%)$, while the contribution of the agricultural sector from Tasikmalaya regency (0.36 $0.43 \%)$, then Garut regency (0.35 - 0.40), Cianjur Regency (0.31 - 0.36\%), Pangandaran Regency $(0.25-0.33 \%)$ and Subang Regency $(0.27-0.30 \%)$.

The rate of economic growth in West Java ranges from 5.04 - $6.50 \%$, where in 2017 the economic growth of West Java was 5.35 percent and in 2018 it increased to 5.64 percent. Regency Economic Growth Rate Bogor, Kab. Kuningan, Kab. Subang, Kab. Purwakarta, Kab. Karawang, Kab. Bekasi has almost the same rate of economic growth in West Java Province. While the rate of economic growth in the regency. Sukabumi, Kab. Cianjur, Kab. Bandung, Garut, Tasikmalaya, Ciamis, Cirebon, Majalengka, Sumedang, West Bandung, Pangandaran is $1-2 \%$ lower than the rate of economic growth in West Java Province. The economic growth rate of the Indramayu Regency is low, ranging between $0.08-2.16 \%$. Enough good economic growth is needed to maintain economic stability and job creation.

LQ calculation uses the Gross Regional Domestic Product (GRDP) based on the 2010 constant prices with the 20102018 observation period. From the LQ analysis of the agriculture sector of each regency against the GRDP of the period 2010-2018 it can be seen that regencies are a sector basis or have a LQ value> 1, that is Sukabumi, Cianjur, Garut, Tasikmalaya, Ciamis, Kuningan, Cirebon, Majalengka, Sumedang, Indramayu, Subang, West Bandung, Pangandaran is a base sector because the sector is able to produce to meet the needs of their own regions and even exports to other regions. A sector is said to be superior if certain regional sectors are able to compete with the same sectors produced by other regions in the national and domestic markets. While those that are not a base sector $(\mathrm{LQ}<1)$ are the agriculture sector from Bogor, Bandung, Purwakarta, Karawang, and Bekasi.

\subsection{The Influence of the Regency Agriculture Sector on the Economic Growth Rate}

Based on the Location Quotient (LQ) analysis, it is known that the regency's agricultural sector is included in the base sector. Next is multiple regression analysis which is a general statistical method used to examine the relationship between a dependent variable $(\mathrm{Y})$ the rate of economic growth with several independent variables (X) LQ base sector. The purpose of multiple regression analysis using the values of known independent variables is to predict the value of the dependent variable. Classification of the variables are as follows:

a. Bound Variables (Y) : economic growth rate (\%)

b. Independent Variable (X) : base sector, namely LQ Agricultural sector Sukabumi $\left(\mathrm{X}_{1}\right)$, LQ Agriculture Sector Cianjur $\left(\mathrm{X}_{2}\right)$, LQ Agriculture Sector Garut $\left(\mathrm{X}_{3}\right)$, LQ Agriculture Sector Tasikmalaya $\left(\mathrm{X}_{4}\right)$, LQ Agricultural sector Ciamis $\left(\mathrm{X}_{5}\right)$, LQ Agricultural sector Kuningan $\left(\mathrm{X}_{6}\right)$, LQ Agricultural sector Cirebon $\left(\mathrm{X}_{7}\right)$, LQ Agricultural sector Majalengka $\left(\mathrm{X}_{8}\right), \quad$ LQ Agriculture Sector Sumedang ( $\left.\mathrm{X}_{9}\right)$, LQ Agriculture Sector Indramayu $\left(\mathrm{X}_{10}\right)$, LQ Agriculture Sector Subang 
$\left(\mathrm{X}_{11}\right)$, LQ Agriculture Sector West Bandung $\left(\mathrm{X}_{12}\right)$, and LQ Agricultural Sector Pangandaran $\left(\mathrm{X}_{13}\right)$

To determine the effect of the the base agricultural sector on the rate of economic growth in West Java Province, the statistical method used is multiple regression analysis, the model is:

$$
\mathrm{Y}=\mathrm{a}+\mathrm{b}_{1} \mathrm{X}_{1}+\mathrm{b}_{2} \mathrm{X}_{2}+\mathrm{b}_{3} \mathrm{X}_{3}+\ldots \ldots \ldots \ldots+\mathrm{b}_{13} \mathrm{X}_{13}
$$

After testing the classical assumptions (normality test, autocorrelation test, multicollinearity test and heteroscedastity test) and the results meet the requirements for the BLUE model and from several regression models produced where the independent variable has a significant influence on the rate of economic growth in Bogor Regency is the $4^{\text {th }}$ model. This can be seen from Sig. $t$ where for each variable has a value smaller than the level of 0.05 (real) with the estimation results of the equation model as follows:

a. Regression Equation:

$$
\mathrm{Y}=14,16+0,27 \mathrm{X}_{3}-2,12 \mathrm{X}_{5}+7,82 \mathrm{X}_{5}-6,10 \mathrm{X}_{5}+1,53
$$$$
\mathrm{X}_{5}-1,45 \mathrm{X}_{5}+0,58 \mathrm{X}_{5}
$$

b. Test simultaneously (F-stat)

Based on the estimation results, it can be concluded that the simultaneous test ( $\mathrm{F}$ test) of the LQ variables of the agricultural sector, Sukabumi $\left(\mathrm{X}_{1}\right)$, LQ Agriculture Sector Tasikmalaya $\left(\mathrm{X}_{4}\right)$, LQ Agricultural sector Cirebon $\left(X_{7}\right)$, LQ Agricultural sector Sumedang $\left(X_{9}\right)$, LQ Agriculture Sector Indramayu $\left(\mathrm{X}_{10}\right)$, LQ Agriculture Sector Subang $\left(X_{11}\right)$, and LQ Agriculture Sector Pangandaran $\left(\mathrm{X}_{13}\right)$ which significantly influences the rate of economic growth in West Java Province, or can be interpreted as rejecting the $\mathrm{H} 0$ hypothesis and accepting the $\mathrm{H} 1$ hypothesis. This can be seen from the F value of 9,904 with Sig. of 0.045 which is still smaller than the significant level of 5\% (0.05).

c. $\mathrm{R}^{2}$ test (coefficient of determination)

$R$ value of 0.78 so that the R-square obtained 0.61 can be interpreted that the variable LQ Agriculture sector Sukabumi $\left(\mathrm{X}_{1}\right)$, LQ Agriculture Sector Tasikmalaya $\left(\mathrm{X}_{4}\right)$, LQ Agricultural sector Cirebon $\left(\mathrm{X}_{7}\right)$, LQ Agricultural sector Sumedang $\left(X_{9}\right)$, LQ Agriculture Sector Indramayu $\left(\mathrm{X}_{10}\right)$, LQ Agriculture Sector Subang $\left(\mathrm{X}_{11}\right)$, and LQ Agriculture Sector Pangandaran $\left(\mathrm{X}_{13}\right)$ can explain the variability of $61.0 \%$ of the variable $\mathrm{Y}$ (economic growth rate), while the rest is explained by other variables not included in the model

d. Partial Test (T-Stat)

1) Every increase in LQ in the agricultural sector Sukabumi $\left(\mathrm{X}_{1}\right) 1$ unit will increase the rate of economic growth by $0.27 \%$, assuming the other variables remain (constant).

2) Every increase Every increase in LQ Agriculture sector Tasikmalaya $\left(\mathrm{X}_{4}\right) 1$ unit will reduce the rate of economic growth by $2.12 \%$, assuming the other variables remain (constant).

3) Every increase in LQ in the agricultural sector Cirebon $\left(\mathrm{X}_{7}\right) 1$ unit will increase the rate of economic growth by $7.82 \%$, assuming the other variables remain (constant).

4) Every increase in LQ in the agricultural sector Sumedang $\left(\mathrm{X}_{9}\right) 1$ unit will reduce the rate of economic growth by $6.10 \%$, assuming the other variables remain (constant).

5) Every increase in LQ in the agricultural sector Indramayu $\left(\mathrm{X}_{10}\right) 1$ unit will increase the rate of economic growth by $1.53 \%$, assuming the other variables remain (constant).

6) Every increase in LQ in the agricultural sector Subang $\left(\mathrm{X}_{11}\right) 1$ unit will reduce the rate of economic growth by $1.45 \%$, assuming the other variables remain (constant).

7) Every increase in LQ in the agricultural sector Pangandaran $\left(\mathrm{X}_{13}\right) 1$ unit will increase the rate of economic growth by $0.58 \%$, assuming the other variables remain (constant).

\section{CONCLUSION}

Based on the results of the discussion the rate of economic growth in West Java ranged from $5.04-6.50 \%$.san and referring to the purpose of the study, then some conclusions can be drawn as follows:

a. The agricultural sector which is the base sector is Sukabumi, Cianjur, Garut, Tasikmalaya, Ciamis, Kuningan, Cirebon, Majalengka, Sumedang, Indramayu, Subang, West Bandung, and Pangandaran regency.

b. Agricultural sectors that have a significant effect on the rate of economic growth in West Java are Sukabumi, Tasikmalaya, Cirebon, Sumedang, Indramayu, Subang, and Pangandaran regency.

\section{ACKNOWLEDGMENT}

Thank you to the Kemenristekdikti who have funded this research through a master's thesis grant.

\section{REFERENCES}

[1] Blakely and Bradshaw, 2002. Planning Local Economic Development.Theory and Practice. Sage Publication, London.

[2] Todaro, P Michael dan Smith, C Stephen, 2003. Pembangunan Ekonomi Di Dunia Ketiga. Erlangga. Jakarta

[3] Bendavid-Val, A. (1991) Regional and Local Economic Analysis for Practitioners. Fourth Edition. Westport, CT: Praeger Publisher.

[4] Kuncoro, Mudrajad, 1977. Ekonomi Pembangunan Teori, Masalah, dan Kebijakan Cetakan pertama. Yogyakarta: UPP AMP YKPN.

[5] Sjafrizal, (2008) Ekonomi Regional. Teori dan Aplikasi. Baduose Media. Padang Sumatera Barat.

[6] Simatupang, P. dan Nizwar Syafa'at, 2000. Industrialisasi Berbasis Pertanian Sebagai Grand Strategy Pembangunan Ekonomi Nasional. Jurnal Forum Penelitian Agro Ekonomi Vol. 18 No. 1 dan 2 
[9] Badan Pusat Statistik (BPS) Kabupaten Cianjur,

Desember 2000. Pusat Penelitian Sosial Ekonomi Pertanian Badan Penelitian dan Pengembangan Pertanian Departemen Pertanian. Bogor.

[7] Badan Pusat Statistik (BPS) Propinsi Jawa Barat, 2018. PDRB Menurut Lapangan Usaha 2010-2018. BPS Propinsi Jawa Barat.

[8] Badan Pusat Statistik (BPS) Kabupaten Bogor, 2018. PDRB Menurut Lapangan Usaha 2010-2018. BPS Kabupaten Bogor. 2018. PDRB Menurut Lapangan Usaha 2010-2018. BPS Kabupaten Cianjur.

[10] Badan Pusat Statistik (BPS) Kabupaten Subang, 2018. PDRB Menurut Lapangan Usaha 2010-2018. BPS Kabupaten Subang. 